\title{
Diet of invasive lionfish on hard bottom reefs of the Southeast USA: insights from stomach contents and stable isotopes
}

\author{
Roldan C. Muñoz ${ }^{1, *}$, Carolyn A. Currin ${ }^{2}$, Paula E. Whitfield ${ }^{2}$ \\ ${ }^{1}$ National Marine Fisheries Service, Beaufort Laboratory, National Oceanic and Atmospheric Administration, Beaufort, \\ North Carolina 28516, USA \\ ${ }^{2}$ National Ocean Service, Center for Coastal Fisheries and Habitat Research, National Oceanic and Atmospheric \\ Administration, Beaufort, North Carolina 28516, USA
}

\begin{abstract}
The Indo-Pacific lionfish (Pterois volitans and P. miles complex) has become widely established along the United States Southeast coast and continues to colonize the Caribbean, yet its biology and ecology is only beginning to be understood. We used stomach contents and stable isotope analyses to determine the diet of lionfish in the warm-temperate hard bottom reef community in the Southeast US Atlantic Ocean. During June to August 2004 and 2006, we collected lionfish with SCUBA from 18 different locations in Onslow Bay, North Carolina, at depths of 30 to 45 m. In 2006, we also conducted visual surveys of small benthic fishes to estimate the abundances of potential prey. Analyses of stomach contents $(n=183)$ and stable isotopes $(n=115)$ suggest a generalist carnivorous diet, and prey categories were predominately fish ( 99\% of total volume) from 16 families. Major differences in the importance of prey occurred between years. Serranidae and Scaridae dominated the diet in 2004, while Haemulidae and Carangidae were important in 2006. Analyses of visual prey surveys did not reveal specialization on particular prey taxa but instead suggest that prey are consumed in relation to their local abundance. Given current theory pertaining to invasive species impacts, the expanding lionfish distribution, and observations that lionfish appear capable of settling to many different habitat types, the overall pattern of generalist piscivory emerging from these data indicates the potential for significant impacts to the invaded community.
\end{abstract}

KEY WORDS: Marine invasion · Rocky reef - Scorpaenidae - Warm temperate Continental shelf Piscivory · Diet · Prey

\section{INTRODUCTION}

Invasive species are a major threat to biological diversity. They have the potential to transform marine habitats worldwide, and to cause hundreds of billions of dollars in economic damages (reviews in Strayer et al. 2006, Molnar et al. 2008). Predators are known to have profound effects on the structure of marine communities, and have been shown capable of enhancing species diversity (keystone species) and altering community structure (trophic cascades) (Paine 1966, Estes et al. 1998, Rilov 2009). Invasive predators have been implicated as one of the most important causes of declines and extinctions of species worldwide
(Vitousek et al. 1997). Generalist invasive predators that become established might potentially affect a wide range of species, but the risk of local extirpation for native species is thought to be lower than for specialized invasive predators. These, in contrast, would be expected to exert stronger direct impacts on a few species and possibly cause more extensive indirect effects, depending on the ecological status of the targeted prey (Rilov 2009). To determine the ecological impacts of invasive predators, we must understand how they interact with other members of the community and how their arrival and establishment affects community structure (Kalogirou et al. 2007, Rilov 2009). 
Along the United States Southeast Atlantic coast, and in Bermuda and the Bahamas, red lionfish Pterois volitans and devil firefish $P$. miles are now established and are continuing to expand their range in the Caribbean (Morris et al. 2009, Schofield 2009). These 2 species are nearly morphologically identical and $93 \%$ of specimens sampled from the Atlantic as well as North Carolina were P. volitans (Hamner et al. 2007), so hereafter we refer to invasive specimens collectively as lionfish or $P$. volitans. Native to the subtropical and tropical regions of the South Pacific, Indian Ocean, and the Red Sea, lionfish are venomous predators whose popularity in the aquarium trade may have contributed to their introduction to Atlantic waters (Whitfield et al. 2002, Semmens et al. 2004, Ruiz-Carus et al. 2006). Classified as demersal mesocarnivores together with groupers (Serranidae) and snappers (Lutjanidae) (Caillet et al. 1986), lionfish are believed to be opportunistic predators that consume fish, shrimp, and crabs in their native range (Hiatt \& Strasburg 1960, Harmelin-Vivien \& Bouchon 1976, Sano et al. 1984). However, until their recent invasion of the Atlantic and Caribbean, their biology and ecology were poorly understood beyond general descriptions because conclusions from these earlier studies were hampered by small sample sizes ( $\mathrm{n}=1$ to 12 ; Hiatt \& Strasburg 1960, Harmelin-Vivien \& Bouchon 1976, Sano et al. 1984). For example, in the native range, lionfish are reported to have few natural predators (Bernadsky \& Goulet 1991), to attain a size of $38 \mathrm{~cm}$ total length (TL), and to reach depths of $50 \mathrm{~m}$ (Randall et al. 1990). In contrast, lionfish in the invaded range have been found in the stomach contents of piscivorous groupers (Maljkoviç et al. 2008) and have been observed to occur at greater depths (down to $304.8 \mathrm{~m}, \mathrm{R}$. Gilmore unpubl.) and attain sizes larger (47.6 cm TL; J. Morris unpubl.) than in the native range. These depth and size extensions, as well as novel observations of predation on lionfish in the invaded range, probably reflect the paucity of investigations in the native range.

Recent studies of lionfish in the Bahamas are beginning to shed light on their ecology and biology in their invaded range (Morris et al. 2009). Bahamian studies documented lionfish at 5 to 177 times higher densities than in their native range (Grubich et al. 2009), capable of reducing reef fish recruitment by $79 \%$ from experimental patch reefs, and preying mostly on fishes (78\% by volume), including 41 species from 21 families (Albins \& Hixon 2008, Green \& Cote 2009, Morris \& Akins 2009). Based on laboratory studies, 80 adult lionfish along a $1 \mathrm{~km}$ stretch of reef in Eilat (Red Sea) were estimated to cumulatively consume approximately $230 \mathrm{~kg}$ of mostly small-bodied prey fishes per year (Fishelson 1997). The size (and economic importance) of prey consumed in the invaded range may increase, however, as increases in body size (relative to the native range) are known for a variety of invasive species, potentially including lionfish (Grosholz \& Ruiz 2003).

The invaded range, and densities, size attained and depth distribution of lionfish in invaded habitats, together with laboratory studies of food consumption, all indicate the possibility for substantial impacts to both native prey communities and trophic competitors. A comprehensive understanding of the impacts of invasive species requires investigation of interactions at broad geographic scales (Crooks \& Rilov 2009), because impacts may vary as invaders confront and respond to different ecological and physical factors in their invaded range. For example, the narrower depth distribution of lionfish in northern parts of the invaded range may be related to winter water temperatures (Whitfield et al. 2002, Kimball et al. 2004, Ruiz-Carus et al. 2006). Ultimately, the impact of lionfish on populations of potential prey and competitors cannot be assessed without detailed data on food habits (Meister et al. 2005, Ruiz-Carus et al. 2006).

Despite recent studies of potential impacts of lionfish to tropical reef communities in the Bahamas (Albins \& Hixon 2008, Morris \& Akins 2009, Cote \& Maljkoviç 2010), impacts to warm-temperate hard bottom reefs of the Southeast US Atlantic Ocean remain unknown. These hard bottom reefs are well recognized as essential fish habitats that support economically valuable commercial and sport fisheries and an increasingly popular sport diving industry (Struhsaker 1969, Parker \& Ross 1986), and lionfish have become widespread residents in the region (Whitfield et al. 2007, Morris et al. 2009). Additional stressors in the Southeast US Atlantic include multiple non-native marine fish species (Semmens et al. 2004, Schofield et al. 2009), potential increases in winter bottom water temperatures (Parker \& Dixon 1998), and the overfishing of many important predatory reef species (Coleman et al. 1999, Huntsman et al. 1999, Shertzer \& Williams 2008).

We set out to contribute to the understanding of lionfish impacts in their invaded range by determining their diet on hard bottom communities of the Southeast US Atlantic Ocean. Our goal was to assess both immediate (stomach contents) and long-term (isotopes) lionfish diets in combination with data from prey community surveys to make inferences about the specialist or generalist predatory role of lionfish. Stomach contents provided information on ingested prey, representing the animal's diet over the last few hours to days, while stable isotopes offered additional information on the trophic status of lionfish by providing a long-term integration of the diet over previous weeks to months (Cocheret de la Morinière et al. 2003). We then considered these results within the context of native reef fish 
diets, hard bottom community structure, and ecological stressors in the Southeast USA to infer potential impacts (trophic overlap and direct predation) of this invasive fish in these warm-temperate reef systems.

\section{MATERIALS AND METHODS}

During June to August 2004 and 2006, we collected lionfish with spears through daylight hours from 18 continental shelf locations in Onslow Bay, North Carolina, at depths from 30 to $45 \mathrm{~m}$ (Fig. 1, Table S1 in Supplement 1 at www.int-res.com/articles/suppl/ m432p181_supp.pdf) using decompression diving techniques. In 2006, at each site $(n=11)$, we also conducted visual surveys of small benthic fishes to estimate the abundance of potential prey. Visual surveys always took place before collections. The prey fish surveys consisted of one 15 min underwater visual census per site, along a $25 \mathrm{~m}$ long transect (Brock 1954, Samoilys \& Carlos 2000). The width of the transects was restricted to $2 \mathrm{~m}$ and targeted active cryptic (or juve-

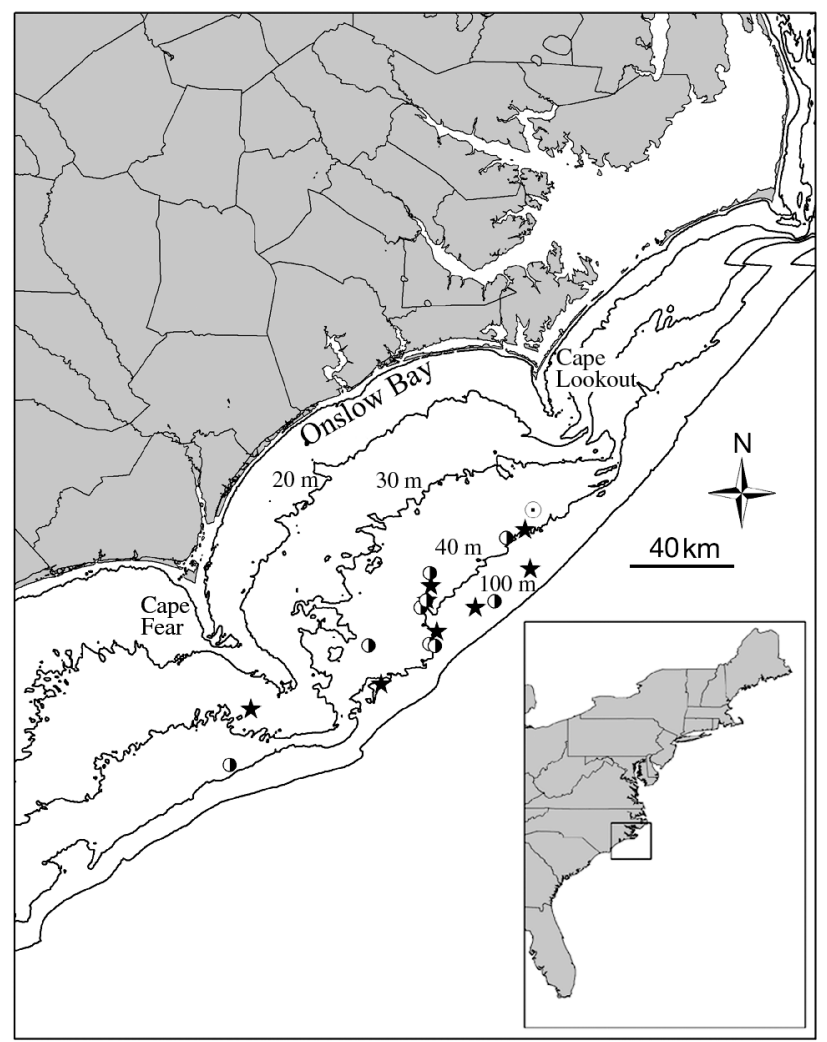

Fig. 1. Coastal North Carolina, showing bathymetric depth zones, (inset) the location of Onslow Bay on the US East Coast, and sampling locations in Onslow Bay in $(\star) 2004,(\odot)$ 2006, and ( both years. Geographic extent of locations ranged from $34^{\circ} 10.523^{\prime} \mathrm{N}$ and $76^{\circ} 31.308^{\prime} \mathrm{W}$ in the north to $33^{\circ} 11.653^{\prime} \mathrm{N}$ and $77^{\circ} 48.434^{\prime} \mathrm{W}$ in the south nile) prey fishes $10 \mathrm{~cm}$ and less in $\mathrm{TL}$, on or above the benthos. This group is often underestimated in surveys of larger conspicuous fishes. However, crevices were not searched, so sedentary or truly cryptic species such as scorpionfish (Scorpaenidae) are unlikely to have been sampled effectively. Because collection of fishes at depth may cause regurgitation (Bowen 1992), we immediately placed speared lionfish in plastic bags to prevent loss of regurgitated stomach contents.

Stomach contents. At the surface, fish were weighed and measured, mouth and gills examined for regurgitated prey (Parrish 1987), and stomachs removed and preserved in $95 \%$ ethanol. We identified prey items in the stomachs to the lowest practical level using a dissecting microscope and published taxonomic keys and reference texts (Dahlberg 1975, Robins et al. 1986, Bohlke \& Chaplin 1993, Hoese \& Moore 1998, McEachran \& Fechhelm 1998, Carpenter 2002a,b, McEachran \& Fechhelm 2006). We blotted the prey items dry, counted, measured and weighed them, and determined their volume by displacement (Hyslop 1980). In 2004, we also removed and froze muscle tissue for isotope analysis. In the laboratory, we rinsed muscle tissue in distilled water, dried it at $60^{\circ} \mathrm{C}$ for $48 \mathrm{~h}$, and then ground the tissue prior to analysis. Results are expressed as $\delta$ values (\%), which represent deviations from the standard reference materials (Fry 1988). Samples were analyzed for $\delta^{13} \mathrm{C}$ and $\delta^{15} \mathrm{~N}$ values with a mass spectrometer at University of California-Davis Stable Isotope Facility.

Isotope analysis. We used a simple 2-source mixing model (Vander Zanden \& Rasmussen 2001) and lionfish $\delta^{13} \mathrm{C}$ values to estimate the contribution of phytoplankton and benthic algae to the lionfish food web. We used a mean $\delta^{13} \mathrm{C}$ value of $-23.5 \%$ for phytoplankton (Fogel et al. 1999), which is consistent with other reports of coastal phytoplankton. There are few reported $\delta^{13} \mathrm{C}$ values for the benthic macroalgae and microalgae, which occur on the shallow portions of the continental shelf and contribute significantly to primary production in the coastal ocean (Cahoon \& Cooke 1992, Jahnke et al. 2000). We used a value of $-17.0 \%$ for benthic algae, which is consistent with values reported from the West Florida Shelf (Fonseca et al. 2006), the Seto Inland Sea (Takai et al. 2002), and the known enrichment in $\delta^{13} \mathrm{C}$ by benthic primary producers (France 1995). We estimated the trophic level at which lionfish are feeding by comparing the $\delta^{15} \mathrm{~N}$ values of the primary producers at the base of the food web with lionfish $\delta^{15} \mathrm{~N}$ values (Fry 1988, Vander Zanden \& Rasmussen 2001). Fogel et al. (1999) report phytoplankton $\delta^{15} \mathrm{~N}$ values averaging $+4 \%$ from the study area, and we assumed that benthic algae would have a similar $\mathrm{N}$ isotope value. We assumed that carnivorous fish muscle tissue is enriched by $3.4 \%$ from its 
prey (Fry 1988, Vander Zanden \& Rasmussen 2001) and that herbivorous fish and invertebrates are enriched by $2.4 \%$ from their food source (Vander Zanden \& Rasmussen 2001, McCutchan et al. 2003).

Statistical analysis. We constructed cumulative prey curves to determine the adequacy of sample sizes (see Supplement 2 at www.int-res.com/articles/suppl/ m432p181_supp.pdf). For each prey category, we calculated mean percent number $(\% \mathrm{n})$, volume $(\% \mathrm{~V})$ and weight $(\% \mathrm{~W})$ from the percentage representation of each prey category in the total number, volume and weight, respectively, of food items for individual lionfish. Rather than pooling prey items across stomachs (sacrificial pseudoreplication) and to quantify the variation around each dietary index, we calculated indices at the level of individual stomachs and then calculated mean values (Ferry \& Caillet 1996, Graham et al. $2007)$. Frequency of occurrence (\%O) was calculated as the number of stomachs that contained one or more of a given prey type expressed as a percentage of all lionfish examined. These data were used to calculate the percent index of relative importance $\left(\% \mathrm{IRI}=\left[\mathrm{IRI}_{i} /\right.\right.$ Total IRI] $\times 100$, where $i=$ a given prey category, IRI $_{i}=$ $\left.\left(\% \mathrm{n}_{i}+\% \mathrm{~V}_{i}\right) \times \% \mathrm{O}_{i}\right)$, and Total IRI = sum of individual IRIs for each prey category (Caillet 1977, Macdonald \& Green 1983, Bowen 1992, Cortes 1997). Percent IRI limits the biases of the individual components of diet analysis and facilitates comparison with other diet studies (Cortes 1997)

We used 1-way analysis of similarities (ANOSIM) tests to examine differences in prey categories, lengths, volume, and number consumed between sampling years, and between prey categories consumed versus prey categories censused during field surveys (see Supplement 3 at www.int-res.com/articles/suppl/m432p181_ supp.pdf). A 2-way ANOSIM with year and lionfish size class as factors was used to examine changes in lionfish diet with size while accounting for any differences between years (see Supplement 4 at www. int-res.com/articles/suppl/m432p181_supp.pdf). Where significant differences were found, similarity percentages (SIMPER) analyses were used to determine the contribution of particular categories responsible for the observed dissimilarities. We used the Mann-Whitney Rank Sum test to examine differences between sizes of lionfish collected between years and to compare the sizes of lionfish consuming crustaceans with those that did not, since these data were not normally distributed. As with nearly all studies of stomach contents from predatory fishes, we sampled specimens that contained prey items that could only be categorized as unidentifiable fish species. However, since different fish species are not expected to show differential digestion rates, we assumed that unidentifiable fish prey came from the same species and in similar pro- portions as identifiable species (Pine et al. 2005). We incorporated unidentifiable fish prey for those analyses that did not depend on the identity of the particular prey item (cumulative prey curve, broad prey categories consumed, distributions of volume and number of prey consumed), and only used recognizable prey items for the remaining analyses. We examined the relationship between fish TL and both $\delta^{13} \mathrm{C}$ and $\delta^{15} \mathrm{~N}$ with linear regression using all data.

\section{RESULTS}

We found lionfish on nearly all habitats we sampled, including high, medium, and low relief natural hard bottoms, algal sand plains, and artificial relief wreck sites. A total of 226 lionfish were collected, 115 in 2004 and 111 in 2006. Of these, $81 \%$ contained food and of these 183 specimens, 96\% contained fish prey (see Table S1 in Supplement 1). Unidentifiable prey fishes accounted for $45 \%$ by both volume and weight, and $57 \%$ by number. The cumulative number of prey categories (18) recorded from these specimens had neared an asymptote and additional estimates of prey items indicated that only 1.5 to 3 prey categories may have been missed by sampling (see Fig. S1 in Supplement 2). In addition, the mean coefficient of variation $(\mathrm{CV})$ of the mean cumulative number of prey taxa generated for the final 4 stomach samples was $0.59 \%$, suggesting that characterizing the diet of lionfish from these samples was sufficiently precise.

Analyses of stomach contents suggest a generalist carnivorous diet. Prey categories included decapod crustaceans (mean $\pm \mathrm{SE}$ volume per stomach $=0.45 \pm$ $0.13 \mathrm{ml}, \mathrm{n}=17$ stomachs), cephalopod and bivalve mollusks $(0.05 \pm 0.05 \mathrm{ml}, \mathrm{n}=2)$, and ophiuroid echinoderms $(0.10 \mathrm{ml}, \mathrm{n}=1)$, but these made up only a fraction of prey contents by volume and number $(3.8 \%$ invertebrates combined). In contrast, a diverse array of prey fishes from 16 different families was observed in the stomachs $(3.77 \pm 0.37 \mathrm{ml}, \mathrm{n}=176$; Table 1, Fig. 2). Goatfishes (Mullidae) and wrasses (Labridae) were the largest prey consumed and grunts (Haemulidae), parrotfishes (Scaridae), and sea basses (Serranidae) were consumed in the greatest abundance (Fig. 2).

Major differences in the importance of prey were seen between years. Serranidae and Scaridae dominated the diet in 2004 while Haemulidae, Carangidae (scad and jacks), and Crustacea were important in 2006 (Fig. 3, 1-way ANOSIM, R = 0.306, p = 0.001; SIMPER, \% contribution to dissimilarity: Serranidae = 22.50, Scaridae $=10.19$, Haemulidae $=20.38$, Carangi dae $=6.99$, Crustacea $=10.54$ ). These differences may have been due to the availability of prey or a reflection of the sizes of lionfish collected between years. Lion- 
Table 1. Pterois volitans. Prey consumed by lionfish off North Carolina. IRI: Index of relative importance (see 'Materials and methods: statistical analysis' for details); n/a: stomach contents regurgitated from multiple fish while in a common holding tank. Unidentifiable fishes represented $45 \%$ of total volume $(664 \mathrm{ml})$ and weight $(616 \mathrm{~g})$, and $57 \%$ of total number (826) of prey fishes recorded from lionfish stomachs

\begin{tabular}{|c|c|c|c|}
\hline Prey category & $\begin{array}{l}\text { Total no. } \\
\text { consumed }\end{array}$ & $\begin{array}{l}\% \text { IRI } \\
2004\end{array}$ & $\begin{array}{l}\% \text { IRI } \\
2006\end{array}$ \\
\hline $\begin{array}{l}\text { Synodontidae } \\
\text { Saurida normani }\end{array}$ & 2 & 0.40 & 0 \\
\hline Scorpaenidae & 1 & 0.07 & 0 \\
\hline Triglidae & 1 & 0 & 0.08 \\
\hline $\begin{array}{l}\text { Serranidae } \\
\text { Tattler bass Serranus phoebe } \\
\text { Belted sandfish } S \text {. subligarius } \\
\text { Harlequin bass } S \text {. tigrinus } \\
\text { Lantern bass } S \text {. baldwini } \\
\text { School bass } S \text { chultzea beta } \\
\text { Sandperch Diplectrum spp. }\end{array}$ & 52 & 70.15 & 0.08 \\
\hline $\begin{array}{l}\text { Apogonidae } \\
\text { Twospot cardinalfish } \\
\text { Apogon pseudomaculatus }\end{array}$ & 11 & 0.40 & 0 \\
\hline $\begin{array}{l}\text { Carangidae } \\
\text { Selar crumenophthalmus }\end{array}$ & 31 & 0.40 & 6.94 \\
\hline $\begin{array}{l}\text { Haemulidae } \\
\text { Haemulon aurolineatum }\end{array}$ & 150 & 0 & 72.83 \\
\hline Mullidae & 1 & $\mathrm{n} / \mathrm{a}$ & $\mathrm{n} / \mathrm{a}$ \\
\hline $\begin{array}{l}\text { Pomacentridae } \\
\text { Chromis enchrysura }\end{array}$ & 8 & 0.24 & 1.58 \\
\hline $\begin{array}{l}\text { Labridae } \\
\text { Bodianus spp., Halichoeres spp. } \\
\text { Thalassoma spp. }\end{array}$ & 9 & 1.71 & 0.38 \\
\hline $\begin{array}{l}\text { Scaridae } \\
\text { Bucktooth parrotfish } \\
\text { Sparisoma radians, Scarus spp. }\end{array}$ & 48 & 18.67 & 0.16 \\
\hline $\begin{array}{l}\text { Blenniidae } \\
\text { Hypleurochilus geminates }\end{array}$ & 22 & 2.94 & 0.41 \\
\hline Gobiidae & 3 & 0 & 1.01 \\
\hline Acanthuridae & 1 & 0 & 0.16 \\
\hline Bothidae & 7 & 0.25 & 1.02 \\
\hline $\begin{array}{l}\text { Monacanthidae } \\
\text { Monacanthus ciliatus }\end{array}$ & 12 & 0.62 & 0.65 \\
\hline $\begin{array}{l}\text { Mollusca } \\
\text { Bivalvia, Cephalopoda }\end{array}$ & 3 & 0.10 & 0.16 \\
\hline $\begin{array}{l}\text { Crustacea } \\
\text { Stomatopoda, Decapoda, Cirripedi }\end{array}$ & dia & 4.06 & 14.55 \\
\hline $\begin{array}{l}\text { Echinodermata } \\
\text { Ophiuroidea }\end{array}$ & 1 & $\mathrm{n} / \mathrm{a}$ & $\mathrm{n} / \mathrm{a}$ \\
\hline
\end{tabular}

fish collected in 2004 were significantly larger than those collected in 2006 (mean \pm SE TL in 2004 vs. 2006: $30.9 \pm 0.53$ vs. $28.4 \pm 0.74$ cm; Mann-Whitney Rank Sum test, $T=13738, \mathrm{n}_{2004}=115, \mathrm{n}_{2006}=111, \mathrm{p}=0.02$ ); and lionfish consuming Crustacea were significantly smaller than lionfish that did not consume Crustacea (TL of samples containing Crustacea vs. those with no Crustacea: $25.9 \pm 1.62$ vs. $29.5 \pm 0.49$ cm; Mann-

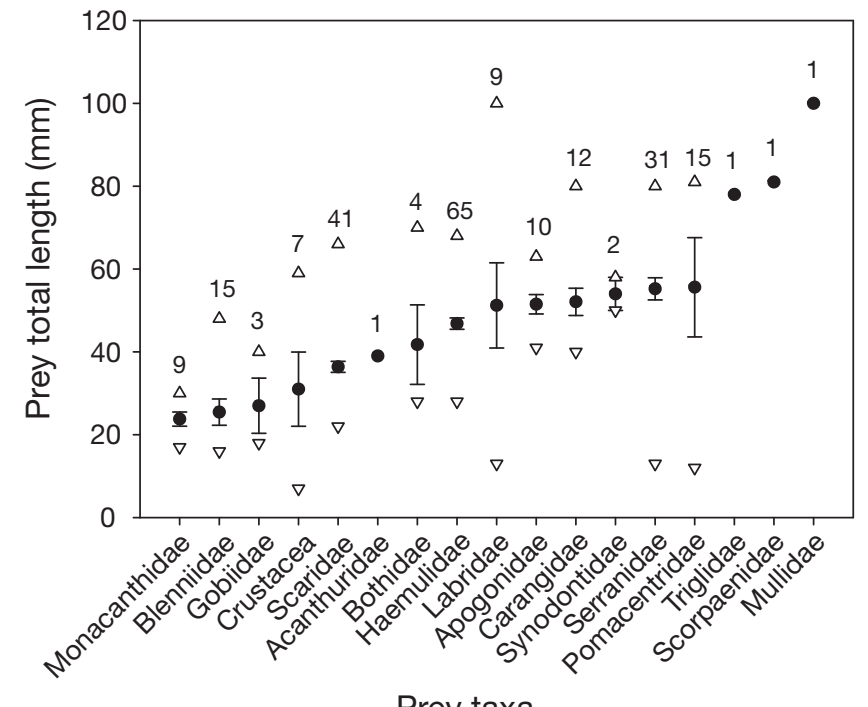

Prey taxa

Fig. 2. Pterois volitans. Size characteristics (TL) of prey categories consumed by lionfish: $(\bullet)$ mean $\pm 1 \mathrm{SE},(\Delta, \nabla)$ maximum and minimum values. Numbers above symbols are number of prey consumed per category

Whitney Rank Sum test, $T=1343, \mathrm{n}_{\text {Crustacea }}=20$, $\left.\mathrm{n}_{\text {no Crustacea }}=163, \mathrm{p}=0.026\right)$. The mean prey/predator TL ratio for 2004 was $0.18 \pm 0.01(\max .0 .41, \mathrm{n}=41)$, compared with $0.16 \pm 0.01$ (max. 0.25, $\mathrm{n}=35$ ) for 2006 and the difference was not significant $\left(t\right.$-test, $t_{74}=1.84$, $\mathrm{p}=0.07)$.

Subtle ontogenetic differences in predatory habit were apparent when examining changes in recognizable prey with lionfish size (2-way ANOSIM, $\mathrm{R}_{\text {year }}=$ $0.344, p=0.001 ; R_{\text {size class }}=0.064, p=0.029$ ). We found that the smallest lionfish contained the greatest proportion by volume of crustacean prey, and higher proportions of small bodied benthic fishes such as gobies (Gobiidae) and blennies (Blenniidae) (Fig. 4, Table S3 in Supplement 4). Their diet was distinct from all other size classes except fish of 25 to $29.9 \mathrm{~cm}$ TL (Table S2 in Supplement 4). With increasing size, the percent volume of larger-bodied prey such as sea basses, parrotfishes, and grunts increased, along with the variety of different prey categories consumed, but the diets of larger size classes of lionfish were not significantly different from each other (Fig. 4, Supplement 4).

Despite the differences in prey consumed between years, general characteristics of prey found in stomachs indicated consistency in lionfish predatory habits. Prey lengths, volumes of stomach contents, and numbers of prey consumed per stomach were similar between years. Mean \pm SE TL of prey in 2004 vs. 2006 was $44.2 \pm 1.7 \mathrm{~mm}, \mathrm{n}=122$ vs. $43.9 \pm 1.5 \mathrm{~mm}, \mathrm{n}=94$ (Fig. 5A; 1 -way ANOSIM, R = 0.01, p > 0.05); mean volume of prey in 2004 vs. 2006 was $3.4 \pm 0.33 \mathrm{ml}, \mathrm{n}=104$ vs. $4.0 \pm 0.72 \mathrm{ml}, \mathrm{n}=79$ (Fig. 5B; 1-way ANOSIM, R = 


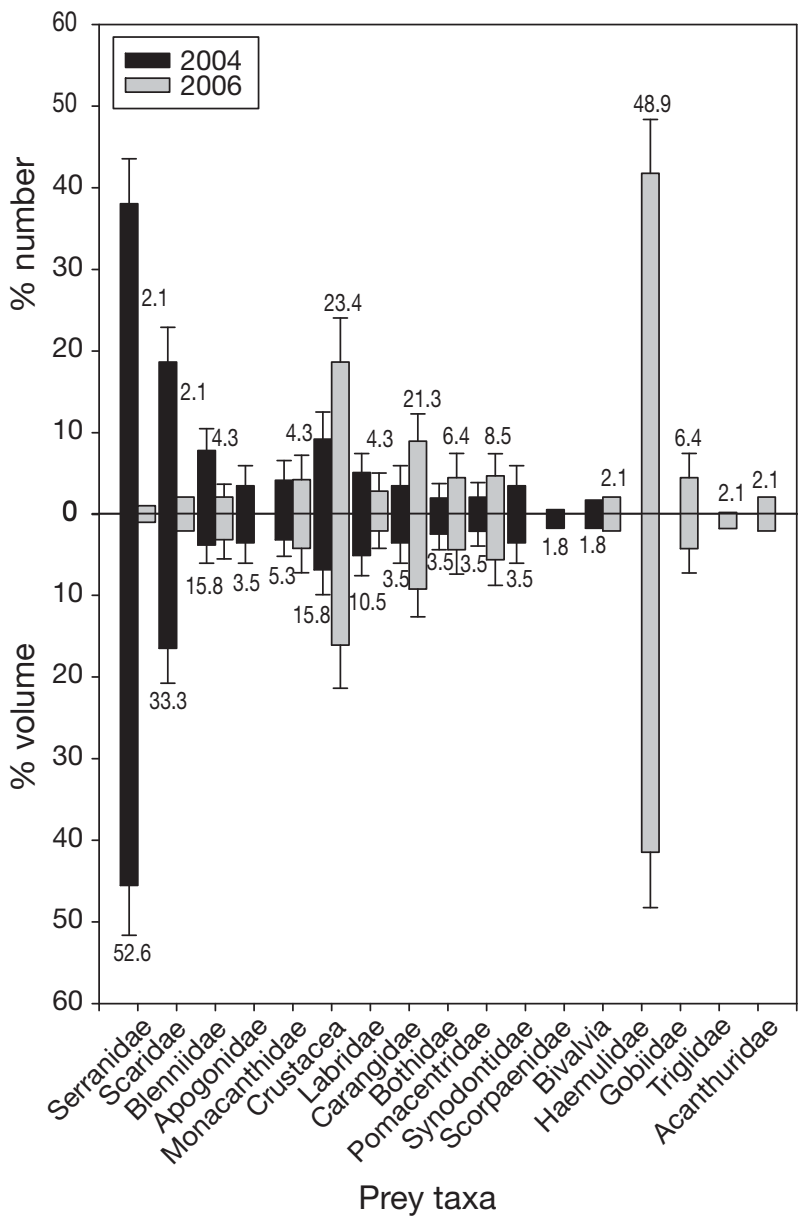

Fig. 3. Pterois volitans. Relative importance of prey categories consumed by lionfish from 2004 and 2006, shown as mean $(+\mathrm{SE})$ percent of total number (upper panel) and total volume (lower panel) of prey consumed. Numbers above and below bars show percent frequency of occurrence for prey categories in 2006 and 2004, respectively

$0.004, \mathrm{p}>0.05)$; mean number of prey per stomach in 2004 vs. 2006 was $4.0 \pm 0.36, \mathrm{n}=104$ vs. $5.5 \pm 1.0, \mathrm{n}=$ 79 (Fig. 5C; 1-way ANOSIM, $\mathrm{R}=0.015, \mathrm{p}=0.035$ ). In the case of number of prey, the low global R statistic indicates that the overall distribution of prey numbers consumed between years, although statistically significant (because of large sample sizes; Warwick 1993, Warwick \& Clarke 2001), was not biologically significant. Visual surveys of prey availability compared with prey from stomach contents revealed that grunts were observed most frequently in the environment and also in the stomachs of lionfish (Fig. 6). Differences between damselfish (Pomacentridae) and scad that were censused versus eaten were not large enough to result in significant differences (1-way ANOSIM, $\mathrm{R}=0.367$, $\mathrm{p}=0.09$ ).

A total of 115 samples collected in 2004 from 17 sites were analyzed for $\delta^{13} \mathrm{C}$ and $\delta^{15} \mathrm{~N}$ values (see Table S1 in Supplement 1). The $\delta^{13} \mathrm{C}$ values of lionfish muscle tissue exhibited little variability between samples, with an overall mean of $-16.60 \pm 0.02 \%$ (range -16.0 to $-17.2 \%$ ). The range in $\delta^{15} \mathrm{~N}$ values was greater (9.61 to $12.07 \%$ ), with an overall mean of $11.00 \pm 0.04 \%$ (Fig. 7). There was no significant relationship between total length of specimens, which ranged between 14.5 and $45.0 \mathrm{~cm}$, and either $\delta^{13} \mathrm{C}(F=0.006, \mathrm{p}=0.9552$, adjusted $\left.\mathrm{r}^{2}=0.0088, \mathrm{df}=114\right)$ or $\delta^{15} \mathrm{~N}(F=2.16, \mathrm{p}=$ 0.1447 , adjusted $\mathrm{r}^{2}=0.0100, \mathrm{df}=114$ ) values of lionfish tissue. Given our previous assumptions regarding $\delta^{15} \mathrm{~N}$ values for benthic algae and tissue enrichment for carnivorous fish, herbivorous fish, and invertebrates (see 'Materials and methods'), there are 2.3 trophic level steps between the mean lionfish $\delta^{15} \mathrm{~N}$ value and primary producers. Assuming a trophic level of 2.3 and a $0.8 \%$ increase in $\delta^{13} \mathrm{C}$ per trophic step, the 2-source mixing model results indicated that benthic primary producers provide about $77 \%$ of the carbon in the lionfish food web.

\section{DISCUSSION}

Our study of stomach contents, prey surveys, and isotope analyses for Pterois volitans off North Carolina indicates a generalist feeding strategy for this invasive fish. Since stomach contents provide only a snapshot of prey consumed, we hoped that samples from multiple years would provide insight regarding the consistency or variability of targeted prey. We found that prey categories that were important (sea basses, parrotfishes) in 2004 were less important in 2006 (when grunts, crustaceans, and scad were the dominant prey items). Although lionfish that had consumed crustaceans were smaller than those that had not and lionfish collected in 2006 were smaller (by approx. $2 \mathrm{~cm}$ ) than those collected in 2004, it is improbable that such dramatic differences in prey consumption were due to the slight size difference in specimens alone. Rather, differences between years are most likely driven by differences in prey availability.

Unfortunately, we did not conduct prey censuses in 2004 so we do not know if these differences in prey importance between years were a response to the local availability of prey. However, our prey community surveys from 2006 do suggest that lionfish consume prey in relation to their availability in the environment rather than preferentially consuming particular prey types, as grunts were the most abundant prey item seen and also the most abundant prey in stomachs. Additionally, although we found a mismatch between scad in stomachs (second most abundant prey species) versus censused (absent from visual surveys), subsequent surveys from multiple years and sites indicate 


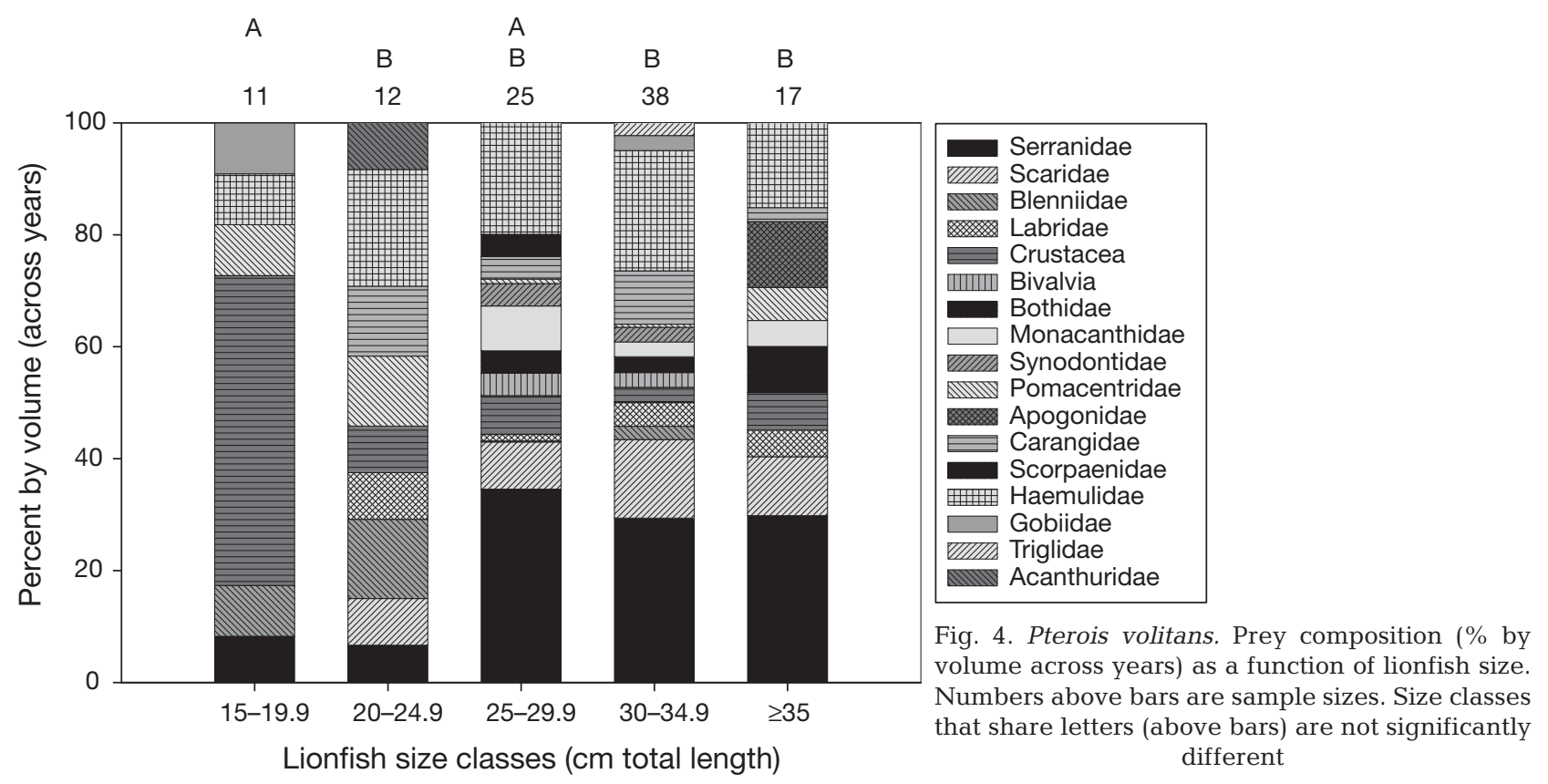

that scad is a patchily distributed species that occasionally visits benthic habitats in large (1100 to 40000 ind. ha ${ }^{-1}$ ) schools while feeding (Parker et al. 1994, Kendall et al. 2009, P. Whitfield et al. unpubl.). Thus, due to their patchy distribution, our visual surveys were unlikely to have effectively censused scad. Tomtate grunts Haemulon aurolineatum and scad Decapterus spp. can be the 2 most abundant species on hard bottom reefs (Parker et al. 1994, Kendall et al. 2009, P. Whitfield et al. unpubl.) and it is likely that scad was one of the most abundant potential prey species in our study area, resulting in a match between availability and consumption. Although the magnitude of damselfishes observed during censuses is greater than that recorded in stomach contents, this same pattern was also found for 2 other studies of piscivorous groupers in such disparate locations as the Great Barrier Reef (GBR) and Hawaii (Beukers-Stewart \& Jones 2004, Dierking et al. 2009). These authors suggested that the close association by damselfishes with the shelter of reefs may make them less vulnerable to predation than mid-water schooling fishes. The groupers Cephalopholis spp. studied at the GBR ate a variety of prey but focused on the 2 most abundant families on the reefs: cardinalfishes (Apogonidae) and damselfishes (Beukers-Stewart \& Jones 2004). When present, however, mid-water schooling herrings (Clupeidae) and fusiliers (Caesionidae) were selected over reef-associated species, similar to our observations of consumption of mid-water schooling grunts and scad. Predators may preferentially attack large schools if school size increases the conspicuousness and detectability of prey (Botham \& Krause 2005), and not all predators succumb equally to the confusion effect attributed to schools (Turesson \& Brönmark 2004). Our density estimates for grunts, scad, and damselfishes suggest that the 3 most abundant prey items observed in lionfish stomachs were also the 3 most abundant prey in the environment. This suggests that prey are generally taken in relation to their local abundance but additional prey surveys coupled with stomach contents are needed to strengthen this conclusion.

The flexibility (across years) in prey consumption and apparent generalist feeding strategy observed for lionfish in this study is consistent with predatory strategies documented for other invasive fishes, including racer goby Neogobius gymnotrachelus and flathead catfish Pylodictis olivaris (Grabowska \& Grabowski 2005, Pine et al. 2005). Available evidence suggests that the most successful fish invaders appear to be piscivorous or omnivorous and ecological generalists (Kolar \& Lodge 2001, Unmack \& Fagan 2004). Such predation strategies likely aid invasive species during establishment in novel environments where the food base may differ from the species' natural range (Grabowska \& Grabowski 2005, Pine et al. 2005), providing an abundance of diverse potential prey resources that would only rarely be limiting (Grabowska \& Grabowski 2005, Rehage et al. 2005). The generalist feeding strategy that we have documented for Pterois volitans indicates one potential mechanism for the success of this invasive piscivore.

Although we found crustaceans, mollusks, and echinoderms in lionfish stomachs, all measures of prey importance indicate that adult lionfish are essentially piscivorous. This designation does not discount the 

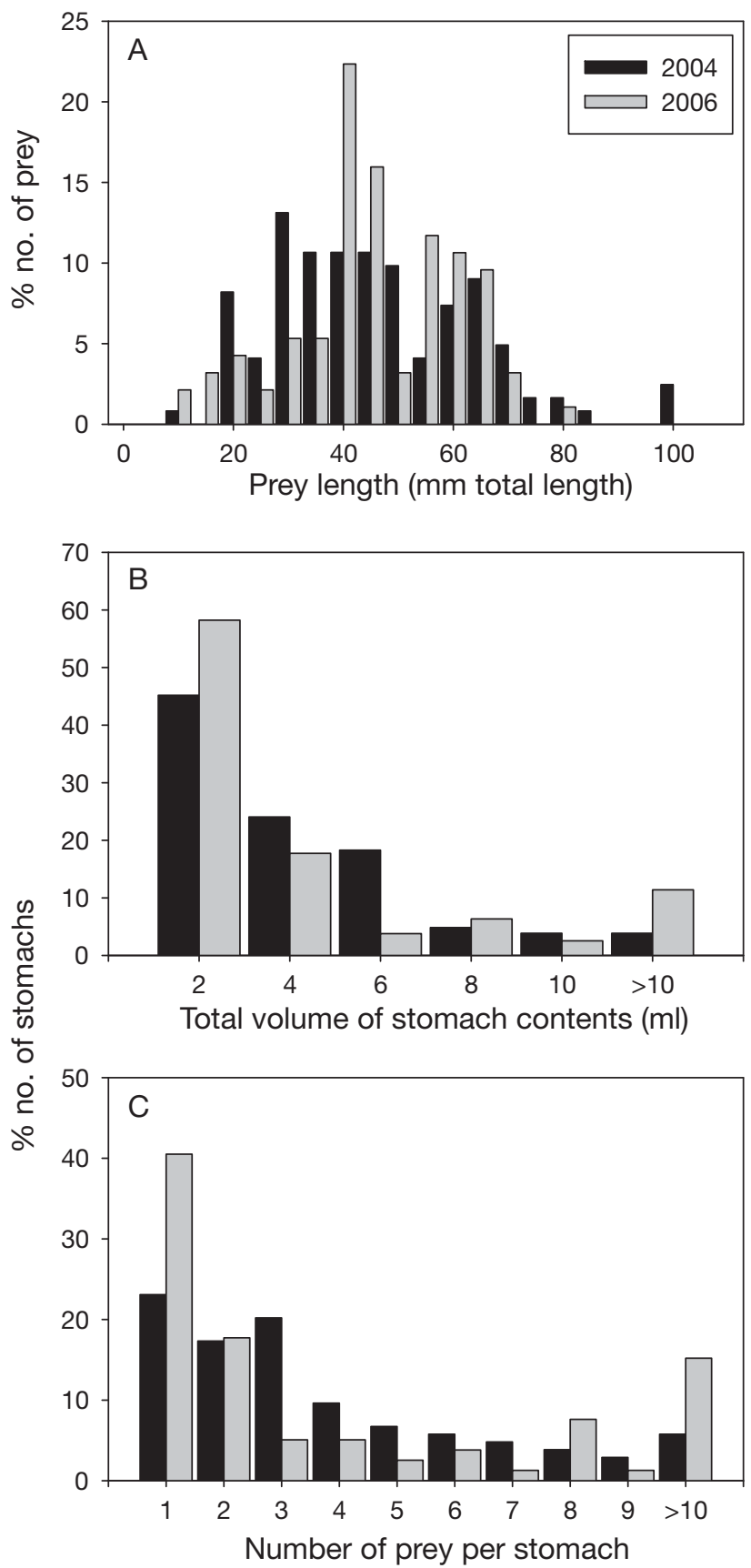

Fig. 5. Pterois volitans. Comparisons between collection years of (A) prey size, (B) volume of stomach contents and (C) number of prey consumed. Sample sizes in 2004 and 2006 respectively were: (A) 122 and 94 prey items, (B, C) 104 and 79 stomachs

finding that smaller lionfish may target invertebrate prey and smaller-bodied fishes, and gradually decrease the quantity of invertebrate prey with ontogeny. Such an ontogenetic shift is a general pattern for numerous piscivores and can result in increased growth rates following the shift (Reñones et al. 2002, Scharf et al. 2009). Morris and Akins (2009) examined

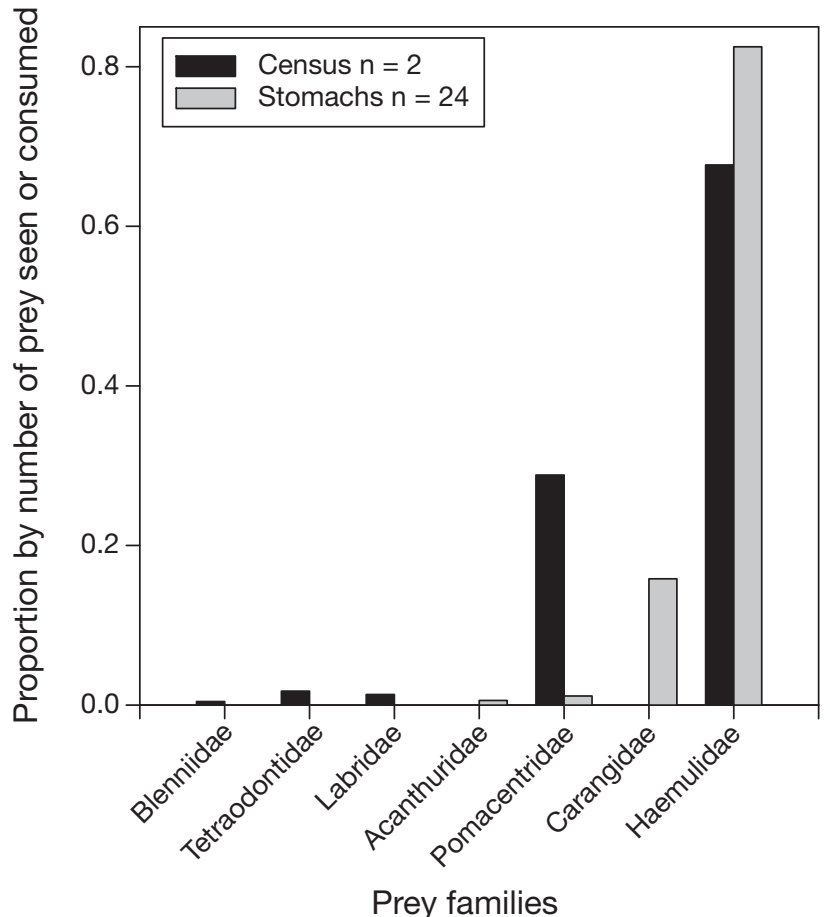

Fig. 6. Pterois volitans. Consumption of lionfish prey (determined from stomach samples) compared with prey availability (determined from prey censuses) in 2006. Data are from the Lobsterrock sites (see Table S1 in Supplement 1) that contained the largest number of stomachs with recognizable prey items

lionfish stomachs from the Bahamas and also found that the proportion of fishes in the diet increased with lionfish size. The specimens they examined were smaller on average $(\mathrm{TL}=21.7 \mathrm{~cm})$ than our North Carolina sample (TL $=28.4$ to $30.9 \mathrm{~cm}$, from 2006 and 2004) and this appears to have influenced the importance of prey as determined through dietary indices, because larger-bodied predators are typically capable of consuming larger-bodied prey (Unmack \& Fagan 2004). Smaller-bodied fishes such as gobies, basslets (Grammatidae), and wrasses were ranked as the most important prey items in the Bahamas; whereas, typically larger-bodied prey (sea basses, grunts, parrotfishes) were most important off North Carolina. In addition, the average prey/predator TL ratio was slightly higher off North Carolina (0.16-0.18 vs. 0.15 in the Bahamas), though the maximum prey/predator TL ratio was higher in the Bahamas (0.48 vs. $0.25-0.41$ in North Carolina) (Albins \& Hixon 2008, Morris \& Akins 2009). Morris \& Akins (2009) found a greater number of families of fish prey (21 vs. 16 off North Carolina) in their samples but also had a larger sample size ( $\mathrm{n}=$ 1069 vs. 183 in the present study). However, a number of prey families found in lionfish from the Bahamas were also found in lionfish from North Carolina. These include grunts, cardinalfish, damselfish, wrasses, par- 


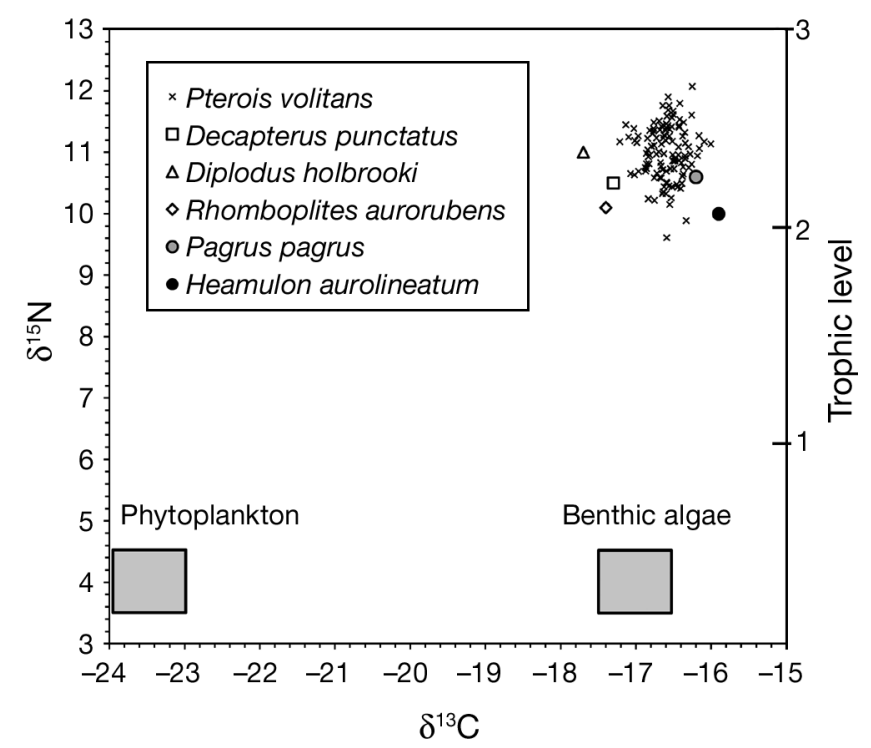

Fig. 7. Plot of stable $\mathrm{C}$ and $\mathrm{N}$ isotope values for Pterois volitans collected in this study $(+)$ and mean values for Onslow Bay reef fishes (Decapterus punctatus, Diplodus holbrooki, Rhomboplites aurorubens, Pagrus pagrus, and Haemulon aurolineatum) from Thomas \& Cahoon (1993). Onslow Bay reef fishes include those utilizing a benthic pathway (filled symbols) and pelagic pathway (open symbols). Estimated trophic level positions of fish are indicated on right side of graph. Boxes for phytoplankton and benthic algae represent the mean $\pm 0.5 \%$ of published isotope values which were used in the mixing model and trophic level calculations

rotfish, blennies, gobies, sea basses, lizardfish (Synodontidae), surgeonfish (Acanthuridae), filefish (Monacanthidae), and goatfish. Prey families unique to North Carolina relative to the Bahamian studies include scorpionfish, sea robins (Triglidae), scad, and flounders (Bothidae).

Stable $\mathrm{N}$ isotopes provide another means of assessing ontogenetic changes in lionfish diets and the trophic level at which lionfish are feeding. The isotope values of muscle tissue integrate diet over a longer period of time than do stomach contents, and reflect the isotope values of all assimilated prey, rather than the identifiable remains of ingested prey. Despite the decrease in percentage of invertebrates found in stomach contents of larger lionfish, we did not see a significant relationship between total length and $\delta^{15} \mathrm{~N}$ values, suggesting that the observed increase in fish consumption with size did not result in a net increase in trophic level. Small fishes that replaced invertebrates in diets of larger lionfish are likely feeding at a similar trophic level as invertebrates, and the utilization of herbivorous fishes such as parrotfish may also contribute to the observed static trophic level with increasing lionfish size. Consumption of rapidly digested (e.g. soft-bodied invertebrates), lower trophic level prey which are not evident in stomach contents (Bowen 1992) may also contribute to the observed $\delta^{15} \mathrm{~N}$ values. The lack of relationship between fish size and $\delta^{15} \mathrm{~N}$ values is in contrast to results from other studies examining marine benthic carnivorous fishes (Reñones et al. 2002, Cocheret de la Morinière et al. 2003), and supports the conclusion that lionfish are generalist feeders. Based on $\delta^{15} \mathrm{~N}$ values, we conclude that lionfish are feeding at a similar trophic level to multiple species of reef fish in Onslow Bay (spottail pinfish Diplodus holbrooki, vermilion snapper Rhomboplites aurorubens, round scad Decapterus punctatus, red porgy Pagrus pagrus, and tomtate Haemulon aurolineatum) reported by Thomas \& Cahoon (1993) (Fig. 7).

The importance of benthic primary producers to the food web supporting lionfish, as determined by the 2-source mixing model, is consistent with analyses of the trophic importance of benthic algae to fishes occupying other shallow nearshore waters (Thomas \& Cahoon 1993, Reñones et al. 2002, Takai et al. 2002, Fonseca et al. 2006). Lionfish $\mathrm{C}$ isotope values are also intermediate to those reported for the 5 species of reef fishes $(-15.9$ to $-17.7 \%$ ) collected from Onslow Bay, which were described as representative of separate planktonic and benthic trophic pathways (Thomas \& Cahoon 1993; our Fig. 7). The range and average $\delta^{13} \mathrm{C}$ values $(-16.0$ to -17.2 , and $-16.6 \%$, respectively) of lionfish collected off North Carolina overlap with values for piscivore ( -16.3 to $-17.6 \%$ ) and opportunistic generalist ( -15.8 to $-18.0 \%$ ) fishes from the literature (Fry 1988), providing additional support that lionfish feed as generalists.

\section{Potential impacts - trophic overlap and direct predation}

Since lionfish appear to be generalist predators that feed primarily on benthic fishes, there is potential in the invaded range for trophic overlap with native fishes that share prey resources (See Table S4 in Supplement 5 at www.int-res.com/articles/suppl/m432 p181_supp.pdf) as well as direct impacts to prey community structure via predation (Randall 1967, Sano et al. 1984, Naughton \& Saloman 1985, Matheson et al. 1986, Fishelson 1997). For example, economically important groupers in the genus Mycteroperca feed almost exclusively on fishes (Randall 1967, Dodrill et al. 1993), and scamp grouper (M. phenax) overlap in habitat utilization and size classes with lionfish (R. Muñoz \& P. Whitfield unpubl.). Like lionfish, serranids, haemulids, and carangids are some of the most important food items in the scamp diet (Matheson et al. 1986), so comparably sized scamp and lionfish may be targeting similar prey, potentially resulting in negative 
trophic impacts from the growing lionfish population if their shared prey resource became limited.

Our ongoing research examining juvenile and cryptic fish (lionfish prey) community structure on hard bottoms is shedding light on potential predatory impacts. Given that we found $100 \mathrm{~mm}$ prey items in lionfish stomachs, that maximum prey/predator TL ratios were 0.41 (or 0.48 if we use Bahamas estimates), and that a $47 \mathrm{~cm}$ (1435 g) lionfish was landed off North Carolina (J. Morris unpubl.), prey up to $22.5 \mathrm{~cm}$ TL could potentially be consumed by lionfish in the Southeast US Atlantic. This estimate is larger than the 8 to $9 \mathrm{~cm}$ TL reported by Fishelson (1997) in the laboratory, but the largest lionfish he studied also weighed less (1006 g) than the specimen from North Carolina. During our ongoing research, we regularly observe lionfish together with the juveniles of a variety of economically important species such as black seabass Centropristis striata, vermilion snapper, white grunt Haemulon plumierii, and scamp grouper at sizes $(<10$ to $20 \mathrm{~cm}$ ) such that they could be directly consumed by lionfish (R. Muñoz \& P. Whitfield unpubl.). Indeed, Morris \& Akins (2009) found economically important yellowtail snapper Ocyurus chrysurus and Nassau grouper Epinephelus striatus in the stomachs collected from Bahamian lionfish.

On the other hand, numerous Atlantic fishes are capable of consuming venomous scorpaenids, including goosefish Lophius americanus and mutton snapper Lutjanus analis, which are known to consume the venomous scorpaenid blackbelly rosefish Helicolenus dactylopterus and spotted scorpionfish Scorpaena plumieri, respectively (Randall 1967, Bowman et al. 2000). In addition, lionfish were recently documented in the stomachs of tiger groupers Mycteroperca tigris and Nassau groupers in the Bahamas (Maljkoviç et al. 2008). At this stage, however, the potential role of predation in decreasing the number of lionfish is unknown, as is the effect of lionfish on native predators. Predation by large carnivores such as groupers and sharks may represent one of the best controls for invasive lionfish (Albins \& Hixon 2008), as low densities $\left(\sim 2.2\right.$ ind. $\left.\mathrm{ha}^{-1}\right)$ of lionfish were observed in their native range on Palauan reefs with robust grouper populations (Grubich et al. 2009).

\section{Lionfish: a permanent component of the Western Atlantic fish community}

Piscivores are believed most capable of altering the communities which they invade (Marchetti et al. 2004) and the overall pattern of generalist piscivory emerging from this study and others (Albins \& Hixon 2008, Morris \& Akins 2009, Cote \& Maljkoviç 2010) indicates the potential for significant impacts to the invaded community. In addition to the diversity of habitats occupied off the North Carolina coast (P. Whitfield et al. unpubl.), lionfish have also been found in Bahamian mangroves (Morris \& Akins 2009, Barbour et al. 2010). Therefore, in southern locations where winter water temperatures more closely resemble those found in the native range, lionfish can be expected to eventually occupy a variety of inshore and offshore habitats. Because of their planktonic larval dispersal and their opportunistic colonization of habitats and use of food resources, we caution that eradication of lionfish will not be feasible. Sustained control measures may mitigate the eventual extent of lionfish populations, but only on a local scale, and the costs of these efforts will need to be carefully evaluated. Fortunately, lionfish are a popular food fish in their native range and aside from the care required in avoiding spines once collected, they are one of the easiest fishes to capture by spear. Therefore, developing and encouraging a fishery for lionfish should be an important part of local control efforts.

In addition to trophic and predatory impacts outlined here, further indirect effects are possible and remain to be investigated in the Southeast US Atlantic. These effects may be related to the overfishing of many groupers and other native predators (Coleman et al. 1999, Huntsman et al. 1999, NMFS 2010) or invasional meltdown (Simberloff \& Von Holle 1999, Grosholz 2005) or interactions with other non-native marine fishes (Semmens et al. 2004, Schofield et al. 2009). The combined effects of overfishing, climate change, and multiple invasive species on ecosystems are not well understood but have been implicated in ecosystem state shifts and decline in several marine ecosystems (Harris \& Tyrrell 2001, Stachowicz et al. 2002, Frank et al. 2005, Grosholz 2005).

Acknowledgements. This work was funded by NOAA's Undersea Research Center in Wilmington, North Carolina, the NOAA Aquatic Invasive Species Program, and the NOAA Beaufort Laboratory-Center for Coastal Fisheries and Habitat Research. D. Kesling, J. Styron, and G. Taylor, provided technical dive training, oversaw dive operations, and collected specimens. C. Addison, C. Coy, B. Degan, J. Hoyt, W. Freshwater, T. Potts, and C. Shemanski assisted with collections and dive operations. M. Lacroix and P. Maddi assisted in sample processing. D. Ahrenholz, T. Kellison, C. Taylor, and 4 anonymous reviewers provided helpful comments on the manuscript.

\section{LITERATURE CITED}

Albins MA, Hixon MA (2008) Invasive Indo-Pacific lionfish Pterois volitans reduce recruitment of Atlantic coral-reef fishes. Mar Ecol Prog Ser 367:233-238

Barbour AB, Montgomery ML, Adamson AA, Diaz-Ferguson 
E, Silliman BR (2010) Mangrove use by the invasive lionfish Pterois volitans. Mar Ecol Prog Ser 401:291-294

Bernadsky G, Goulet D (1991) A natural predator of the lionfish Pterois miles. Copeia 230-231

Beukers-Stewart BD, Jones GP (2004) The influence of prey abundance on the feeding ecology of 2 piscivorous species of coral reef fish. J Exp Mar Biol Ecol 299:155-184

Bohlke JE, Chaplin CC (1993) Fishes of the Bahamas and adjacent tropical waters. University of Texas Press, Austin, TX

$>$ Botham MS, Krause J (2005) Shoals receive more attacks from the wolf-fish (Hoplias malabaricus Bloch, 1794). Ethology 111:881-890

Bowen SH (1992) Quantitative description of the diet. In: Nielsen LA, Johnson DL (eds) Fisheries techniques. Southern Printing Company, Blacksburg, VA, p 325-336

Bowman RE, Stillwell CE, Michaels WL, Grosslein MD (2000) Food of Northwest Atlantic fishes and 2 common species of squid. US Dept Commerce, NOAA Tech Memo NMFS NE 155

Brock VE (1954) A preliminary report on a method of estimating reef fish populations. J Wildl Manag 18:297-308

> Cahoon LB, Cooke JE (1992) Benthic microalgal production in Onslow Bay, North Carolina, USA. Mar Ecol Prog Ser 84:185-196

Caillet GM (1977) Several approaches to the feeding ecology of fishes. In: Simenstad CA, Lipovsky SJ (eds) Fish food habits studies. Proc 1st Pacific NW Technical Workshop, University of Washington, Seattle, WA, p 1-13

Caillet GM, Love MS, Ebeling AW (1986) Fishes, a field and laboratory manual on their structure, identification, and natural history. Waveland Press, Prospect Heights, IL

Carpenter KE (ed) (2002a) The living marine resources of the Western Central Atlantic, Vol 2. Bony fishes Part 1. Food and Agriculture Organization, Rome

Carpenter KE (ed) (2002b) The living marine resources of the Western Central Atlantic, Vol 3. Bony fishes Part 2. Food and Agriculture Organization, Rome

Cocheret de la Morinière E, Pollux BJA, Nagelkerken I, Hemminga MA, Huiskes AHL, van der Velde G (2003) Ontogenetic dietary changes of coral reef fishes in the mangrove-seagrass-reef continuum: stable isotopes and gut-content analysis. Mar Ecol Prog Ser 246:279-289

Coleman FC, Koenig CC, Eklund AM, Grimes CB (1999) Management and conservation of temperate reef fishes in the grouper-snapper complex of the southeastern United States. In: Musick JA (ed) Life in the slow lane: ecology and conservation of long-lived marine animals. Am Fish Soc Symp 23, Bethesda, MD, p 233-242

Cortes E (1997) A critical review of methods of studying fish feeding based on analysis of stomach contents: application to elasmobranch fishes. Can J Fish Aquat Sci 54:726-738

Cote IM, Maljkoviç A (2010) Predation rates of Indo-Pacific lionfish on Bahamian coral reefs. Mar Ecol Prog Ser 404: 219-225

Crooks JA, Rilov G (2009) Future directions for marine invasions research. In: Rilov G, Crooks JA (eds) Biological invasions in marine ecosystems, Vol 204. Springer-Verlag, Berlin, p 621-625

Dahlberg MD (1975) Guide to coastal fishes of Georgia and nearby states. University of Georgia Press, Athens, GA

Dierking J, Williams ID, Walsh WJ (2009) Diet composition and prey selection of the introduced grouper species peacock hind (Cephalopholis argus) in Hawaii. Fish Bull 107:464-476

Dodrill J, Manooch CS, Manooch AB (1993) Food and feeding behavior of adult snowy grouper, Epinephelus niveatus
(Valenciennes) (Pisces, Serranidae), collected off the central North Carolina coast with ecological notes on major food groups. Brimleyana 19:101-135

Estes JA, Tinker MT, Williams TM, Doak DF (1998) Killer whale predation on sea otters linking oceanic and nearshore ecosystems. Science 282:473-476

Ferry LA, Caillet GM (1996) Sample size and data analysis: Are we characterizing and comparing diet properly? In: MacKinley D, Shearer K (eds) Gutshop '96. Feeding ecology and nutrition in fish: symposium preceedings. American Fisheries Society, San Francisco, CA, p 71-80

Fishelson L (1997) Experiments and observations on food consumption, growth and starvation in Dendrochirus brachypterus and Pterois volitans (Pteroinae, Scorpaenidae). Environ Biol Fishes 50:391-403

Fogel ML, Aguilar C, Cuhel R, Hollander DJ, Willey JD, Paerl HW (1999) Biological and isotopic changes in coastal waters induced by Hurricane Gordon. Limnol Oceanogr 44:1359-1369

Fonseca MS, Uhrin AV, Currin CA, Burke JS and others (2006) Ongoing monitoring of Tortugas Ecological Reserve: assessing the consequences of reserve designation. US Dept Commerce, NOAA Tech Memo NOS NCCOS 22

France RL (1995) Carbon-13 enrichment in benthic compared to planktonic algae: foodweb implications. Mar Ecol Prog Ser 124:307-312

Frank KT, Petrie B, Choi JS, Leggett WC (2005) Trophic cascades in a formerly cod-dominated ecosystem. Science 308:1621-1623

Fry B (1988) Food web structure on Georges Bank from stable C, N, and S isotopic compositions. Limnol Oceanogr 33: $1182-1190$

Grabowska J, Grabowski M (2005) Diel-feeding activity in early summer of racer goby Neogobius gymnotrachelus (Gobiidae): a new invader in the Baltic basin. J Appl Ichthyology 21:282-286

Graham BS, Grubbs D, Holland KN, Popp BN (2007) A rapid ontogenetic shift in the diet of yellowfin tuna from Hawaii. Mar Biol 150:647-658

Green SJ, Cote IM (2009) Record densities of Indo-Pacific lionfish on Bahamian coral reefs. Coral Reefs 28:107

- Grosholz ED (2005) Recent biological invasion may hasten invasional meltdown by accelerating historical introductions. Proc Natl Acad Sci USA 102:1088-1091

> Grosholz ED, Ruiz GM (2003) Biological invasions drive size increases in marine and estuarine invertebrates. Ecol Lett 6:700-705

> Grubich JR, Westneat MW, McCord CL (2009) Diversity of lionfishes (Pisces: Scorpaenidae) among remote coral reefs of the Palau Archipelago. Coral Reefs 28:807

Hamner RM, Freshwater DW, Whitfield PE (2007) Mitochondrial cytochrome $b$ analysis reveals 2 invasive lionfish species with strong founder effects in the western Atlantic. J Fish Biol 71:214-222

Harmelin-Vivien ML, Bouchon C (1976) Feeding behavior of some carnivorous fishes (Serranidae and Scorpaenidae) from Tuléar (Madagascar). Mar Biol 37:329-340

Harris LG, Tyrrell MC (2001) Changing community states in the Gulf of Maine: synergism between invaders, overfishing, and climate change. Biol Invasions 3:9-21

Hiatt RW, Strasburg DW (1960) Ecological relationships of the fish fauna on coral reefs of the Marshall Islands. Ecol Monogr 30:65-127

Hoese HD, Moore RH (1998) Fishes of the Gulf of Mexico, Texas, Louisiana, and adjacent waters. Texas A \& M University Press, College Station, TX 
Huntsman GR, Potts J, Mays RW, Vaughan D (1999) Groupers (Serranidae, Epinephelinae): endangered apex predators of reef communities. In: Musick JA (ed) Life in the slow lane: ecology and conservation of long-lived marine animals. Am Fish Soc Symp 23, Bethesda, MD, p 217-231

Hyslop EJ (1980) Stomach contents analysis - a review of methods and their application. J Fish Biol 17:411-429

Jahnke RA, Nelson JR, Marinelli RL, Eckman JE (2000) Benthic flux of biogenic elements on the Southeastern US continental shelf: influence of pore water advective transport and benthic microalgae. Cont Shelf Res 20:109-127

Kalogirou S, Corsini M, Kondilatos G, Wennhage H (2007) Diet of the invasive piscivorous fish Fistularia commersonii in a recently colonized area of the eastern Mediterranean. Biol Invasions 9:887-896

Kendall MS, Bauer LJ, Jeffrey CFG (2009) Influence of hard bottom morphology on fish assemblages of the continental shelf off Georgia, southeastern USA. Bull Mar Sci 84 265-286

Kimball ME, Miller JM, Whitfield PE, Hare JA (2004) Thermal tolerance and potential distribution of invasive lionfish (Pterois volitans/miles complex) on the east coast of the United States. Mar Ecol Prog Ser 283:269-278

Kolar CS, Lodge DM (2001) Progress in invasion biology: predicting invaders. Trends Ecol Evol 16:199-204

Macdonald JS, Green RH (1983) Redundancy of variables used to describe importance of prey species in fish diets. Can J Fish Aquat Sci 40:635-637

Maljkoviç A, van Leeuwen TE, Cove SN (2008) Predation on the invasive red lionfish, Pterois volitans (Pisces: Scorpaenidae), by native groupers in the Bahamas. Coral Reefs 27:501

Marchetti MP, Moyle PB, Levine R (2004) Invasive species profiling? Exploring the characteristics of non-native fishes across invasion stages in California. Freshw Biol 49:646-661

Matheson RH, Huntsman GR, Manooch CS (1986) Age, growth, mortality, food and reproduction of the scamp, Mycteroperca phenax, collected off North Carolina and South Carolina. Bull Mar Sci 38:300-312

McCutchan JH, Lewis WM, Kendall C, McGrath CC (2003) Variation in trophic shift for stable isotope ratios of carbon, nitrogen, and sulfur. Oikos 102:378-390

McEachran J, Fechhelm JD (1998) Fishes of the Gulf of Mexico, Vol. 1: Myxiniformes to Gasterosteiformes. University of Texas Press, Austin, TX

McEachran J, Fechhelm JD (2006) Fishes of the Gulf of Mexico, Vol. 2: Scorpaeniformes to Tetraodontiformes University of Texas Press, Austin, TX

Meister HS, Wyanski DM, Loefer JK, Ross SW, Quattrini AM, Sulak KJ (2005) Further evidence for the invasion and establishment of Pterois volitans (Teleostei: Scorpaenidae) along the Atlantic coast of the United States. Southeast Nat 4:193-206

Molnar JL, Gamboa RL, Revenga C, Spalding MD (2008) Assessing the global threat of invasive species to marine biodiversity. Front Ecol Environ 6:485-492

Morris JA, Akins JL (2009) Feeding ecology of invasive lionfish (Pterois volitans) in the Bahamian archipelago. Environ Biol Fishes 86:389-398

Morris JA, Akins JL, Barse A, Cerino D and others (2009) Biology and ecology of the invasive lionfishes Pterois miles and Pterois volitans. Proc Gulf Caribb Fish Inst 61:1-6

Naughton SP, Saloman CH (1985) Food of gag (Mycteroperca microlepis) from North Carolina and three areas of Florida. US Dept Commerce, NOAA Tech Memo NMFSSEFC-160
NMFS (National Marine Fisheries Service) (2010) Status of U.S. Fisheries. www.nmfs.noaa.gov/sfa/statusoffisheries/ SOSmain.htm

Paine RT (1966) Food web complexity and species diversity. Am Nat 100:65-75

Parker RO, Dixon RL (1998) Changes in a North Carolina reef fish community after 15 years of intense fishing - global warming implications. Trans Am Fish Soc 127:908-920

Parker RO, Ross SW (1986) Observing reef fishes from submersibles off North Carolina. Northeast Gulf Sci 8:31-49

Parker RO, Chester AJ, Nelson RS (1994) A video transect method for estimating reef fish abundance, composition, and habitat utilization at Gray's Reef National Marine Sanctuary, Georgia. Fish Bull 92:787-799

Parrish JD (1987) The trophic biology of snappers and groupers. In: Polovina JJ, Ralston S (eds) Tropical snappers and groupers: biology and fisheries management. Westview Press, Boulder, CO, p 405-463

Pine WE, Kwak TJ, Waters DS, Rice JA (2005) Diet selectivity of introduced flathead catfish in coastal rivers. Trans Am Fish Soc 134:901-909

Randall JE (1967) Food habits of reef fishes of the West Indies. Stud Trop Oceanogr 5:665-847

Randall JE, Allen GR, Steene RC (1990) Fishes of the Great Barrier Reef and Coral Sea. University of Hawaii Press, Honolulu, HI

Rehage JS, Barnett BK, Sih A (2005) Foraging behaviour and invasiveness: do invasive Gambusia exhibit higher feeding rates and broader diets than their noninvasive relatives? Ecol Freshwat Fish 14:352-360

Reñones O, Polunin NVC, Goni R (2002) Size related dietary shifts of Epinephelus marginatus in a western Mediterranean littoral ecosystem: an isotope and stomach content analysis. J Fish Biol 61:122-137

Rilov G (2009) Predator-prey interactions of marine invaders. In: Rilov G, Crooks JA (eds) Biological invasions in marine ecosystems. Springer-Verlag, Berlin, p 261-285

Robins CR, Ray GC, Douglass J, Freund R (1986) A field guide to Atlantic coast fishes. Houghton Mifflin, Boston, MA

Ruiz-Carus R, Matheson RE, Roberts DE, Whitfield PE (2006) The western Pacific red lionfish, Pterois volitans (Scorpaenidae), in Florida: evidence for reproduction and parasitism in the first exotic marine fish established in state waters. Biol Conserv 128:384-390

Samoilys MA, Carlos G (2000) Determining methods of underwater visual census for estimating the abundance of coral reef fishes. Environ Biol Fishes 57:289-304

Sano M, Shimizu M, Nose Y (1984) Food habits of teleostean reef fishes in Okinawa Island, southern Japan. University of Tokyo Press, Tokyo

Scharf FS, Buckel JA, Juanes F (2009) Contrasting patterns of resource utilization between juvenile estuarine predators: the influence of relative prey size and foraging ability on the ontogeny of piscivory. Can J Fish Aquat Sci 66:790-801

Schofield PJ (2009) Geographic extent and chronology of the invasion of non-native lionfish (Pterois volitans [Linnaeus 1758] and P. miles [Bennett 1828]) in the Western North Atlantic and Caribbean Sea. Aquat Invasions $4: 473-479$

Schofield PJ, Morris JA, Akins JL (2009) Field guide to nonindigenous marine fishes of Florida. US Dept Commerce, NOAA Tech Memo NOS NCCOS 92

> Semmens BX, Buhle ER, Salomon AK, Pattengill-Semmens CV (2004) A hotspot of non-native marine fishes: evidence for the aquarium trade as an invasion pathway. Mar Ecol Prog Ser 266:239-244

Shertzer KW, Williams EH (2008) Fish assemblages and indi- 
cator species: reef fishes off the southeastern United States. Fish Bull 106:257-269

Simberloff D, Von Holle B (1999) Positive interactions of nonindigenous species: invasional meltdown? Biol Invasions $1: 21-32$

Stachowicz JJ, Terwin JR, Whitlatch RB, Osman RW (2002) Linking climate change and biological invasions: ocean warming facilitates nonindigenous species invasions. Proc Natl Acad Sci USA 99:15497-15500

Strayer DL, Eviner VT, Jeschke JM, Pace ML (2006) Understanding the long-term effects of species invasions. Trends Ecol Evol 21:645-651

Struhsaker P (1969) Demersal fish resources: composition, distribution, and commercial potential of the continental shelf stocks off southeastern United States. Fish Ind Res 4:261-300

Takai N, Mishima Y, Yorozu A, Hoshika A (2002) Carbon sources for demersal fish in the western Seto Inland Sea Japan, examined by delta C-13 and delta N-15 analyses. Limnol Oceanogr 47:730-741

Thomas CJ, Cahoon LB (1993) Stable isotope analyses differentiate between different trophic pathways supporting rocky-reef fishes. Mar Ecol Prog Ser 95:19-24

Turesson H, Brönmark C (2004) Foraging behaviour and capture success in perch, pikeperch and pike and the effects

Editorial responsibility: Ivan Nagelkerken, Nijmegen, Netherlands of prey density. J Fish Biol 65:363-375

Unmack PJ, Fagan WE (2004) Convergence of differentially invaded systems toward invader-dominance: time-lagged invasions as a predictor in desert fish communities. Biol Invasions 6:233-243

- Vander Zanden MJ, Rasmussen JB (2001) Variation in $\delta^{15} \mathrm{~N}$ and $\delta^{13} \mathrm{C}$ trophic fractionation: implications for aquatic food web studies. Limnol Oceanogr 46:2061-2066

Vitousek PM, Mooney HA, Lubchenco J, Melillo JM (1997) Human domination of Earth's ecosystems. Science 277: 494-499

Warwick RM (1993) Environmental-impact studies on marine communities-pragmatical considerations. Aust J Ecol 18: 63-80

Warwick RM, Clarke KR (2001) Practical measures of marine biodiversity based on relatedness of species. Oceanogr Mar Biol Annu Rev 39:207-231

Whitfield PE, Gardner T, Vives SP, Gilligan MR, Courtenay WR, Ray GC, Hare JA (2002) Biological invasion of the Indo-Pacific lionfish Pterois volitans along the Atlantic coast of North America. Mar Ecol Prog Ser 235:289-297

Whitfield PE, Hare JA, David AW, Harter SL, Muñoz RC, Addison CM (2007) Abundance estimates of the IndoPacific lionfish Pterois volitans/miles complex in the Western North Atlantic. Biol Invasions 9:53-64

Submitted: June 30, 2010; Accepted: March 31, 2011

Proofs received from author(s): June 2, 2011 